\title{
Persepsi Masyarakat Terhadap Revitalisasi Pasar Dupa Kencana Pekanbaru
}

\author{
Afred Suci \\ Fakultas Ekonomi Universitas Lancang Kuning Pekanbaru \\ Jalan Yos Sudarso KM 8 Rumbai \\ Telp. (0761) 52581 email: afred_75@yahoo.com
}

\begin{abstract}
Study held in Dupa Kencana Market Pekanbaru in order to analyze consumer's perception towards traditional market and its impact to revitalization of Dupa Kencana market. Population consists of Pekanbaru society as the regular consumers. Respondent numbers determined by Hair theory and consists of 70 respondents. Variable used are perception as independent, while the revitalization used as dependent. Data analyzed by using descriptive and simple regression analysis. Study reveals that consumer's perception is still negative but it doesn't significantly raises the intention of them in order to have Dupa Kencana market revitalized. The only revitalization they want is merely zoning revitalization, instead of total revitalization or relocation
\end{abstract}

Keywords: Perception, Revitalization, Traditional Market

Jika dibandingkan dengan pasar modern, maka karakteristik yang sering tercitrakan dari sebuah pasar tradisional adalah kumuh, becek, sumpek, panas, bau, dan sebutansebutan buruk lainnya. Namun pun demikian, pasar tradisional masih mendapatkan tempat di masyarakat mengingat peran pentingnya dalam menggerakkan roda ekonomi pedagang kecil (Sulistyo \& Cahyono, 2010), serta daya tarik tawar menawar yang dapat dilakukan oleh pembeli dalam memenuhi kebutuhan sehari-hari (Slamet, 2010). Terlebih lagi disparitas harga antara pasar tradisional dengan pasar modern juga terpaut cukup jauh, sehingga masyarakat banyak yang masih bertahan pada pasar-pasar tradisional.

Namun demikian, riset yang dilakukan oleh Asosiasi Pedagang Pasar Seluruh Indonesia (APPSI) menyebutkan jumlah pasar tradisional secara kuantitas mengalami penurunan rata-rata $8 \%$ setiap tahun, sementara pasar modern justru tumbuh ratarata $35 \%$ yang terdiri dari hypermarket, ranch market, supermarket, dan mini market (Sulistyo \& Cahyono, 2010). Ini menunjukkan bahwa keberadaan pasar tradisional sedang dalam keadaan yang mengkhawatirkan keberlanjutannya. Kesadaran lingkungan yang semakin tinggi serta didukung dengan meningkatnya daya beli masyarakat diyakini menjadi sebab mengapa pasar-pasar tradisional mulai ditinggalkan oleh konsumen. Kualitas lingkungan yang tidak terpelihara di pasarpasar tradisional, bukan saja menghadirkan ketidaknyamanan masyarakat konsumen, namun secara sosial juga memberikan dampak buruk yang mengganggu ketertiban, keindahan, serta kebersihan lingkungan.

Secara umum, hampir seluruh pasar tradisional minim terhadap pengelolaan manajemen pasar yang baik. Hal ini dikarenakan minimnya keterampilan pengurus pasar dalam manajemen pasar. Ironisnya, keberhasilan pengelolaan pasar seringkali hanya didasarkan pada besarnya retribusi pasar yang diperoleh, namun bukan pada pencapaian indikator kualitas pelayanan pasar kepada para pedagang dan masyarakat konsumen pasar tersebut. Akibatnya, pedagang kios, los, pedagang kaki lima sering menjadi objek pungutan retrbusi belaka tanpa mendapatkan kesempatan untuk dapat dilayani secara baik oleh pengelola pasar. Dampak turunannya adalah, kualitas pelayanan pedagang yang juga rendah terhadap konsumen sebagai efek domino yang terjadi 
(Slamet, 2010). Seringkali pengelola mengabaikan kepatuhan zoning (pembagian area) yang disiplin, contoh pedagang yang memiliki kios dan los sering berbenturan dengan PKL karena berebutan konsumen karena memiliki dagangan yang sejenis dengan penghuni kios/los di dalam pasar. Dalam hal ini, PKL diuntungkan karena sering mengambil tempat di pinggir jalan masuk pasar, sehingga akan lebih dulu berinteraksi dengan konsumen yang hendak ke pasar (Darmawati, 2007). Penelitian Muslimin, et.al (2006) menunjukkan bahwa kondisi infrastruktur pasar tradisional saat ini semakin mengalami penurunan dari tahun ke tahun. Banyak pengelola yang enggan merevitalisasi pasar dengan alasan laba yang berkurang akibat konsumen banyak berpindah ke pasar-pasar modern.

Fenomena ini juga tampak pada salah satu pasar tradisional di kota Pekanbaru, yaitu Pasar Dupa Kencana, yang berada di Jalan Gelatik, Pekanbaru. Pasar Dupa dikelola oleh pihak swasta yang menjalin MoU (Memorandum of Understanding) dengan Pemerintah Kota Pekanbaru. Menurut keterangan dari Unit Pengelola Teknis Dinas Pasar Pekanbaru, pasar ini menempati urutan kedua terburuk pengelolaannya setelah Pasar Sukaramai. Penilaian negatif dari Pasar Dupa terutama timbul dari aspek pengendalian lingkungan bersih seperti, sistem drainase, sampah, dan penghijauan (http://www.riauterkini.com, 5/2/2011). Bahkan pengelola Pasar Dupa ditegur keras secara tertulis untuk segera merapikan kondisi pengendalian lingkungan, ketertiban pedagang kaki lima, perparkiran, dan kebersihan pasar, jika tidak ijin usaha akan segera dicabut (http://www.riauterkini.com, 8/2/2011).

Observasi awal peneliti juga mengkonfirmasi apa yang selama ini menjadi keluhan Pemerintah Kota mengenai higienitas, ketertiban, dan kenyamanan Pasar Dupa. Saluran air kotor hanya disalurkan melalui kanal-kanal kecil yang langsung dialirkan ke sungai yang berada di belakang lokasi pasar. Air di WC umum juga nyaris tidak ada, sehingga kotoran dan bau pesing sangat terasa menyengat penciuman. Lokasi pasar yang berada dekat pemukiman, juga mengakibatkan lingkungan menjadi terasa kumuh. Belum lagi masyarakat yang juga ikut membuang sampah di pasar, sedangkan pasar sendiri tidak memiliki sistem penampungan sampah yang baik.

Dari hasil wawancara yang dilakukan terhadap masyarakat yang tinggal di sekitar lokasi pasar diperoleh informasi bahwa mereka telah lama mengeluh terhadap kondisi di Pasar Dupa Kencana. Bau menyengat seringkali sampai ke rumahrumah mereka. Selain bau, kondisi di dalam rumah dan pekarangan penduduk sekitar juga penuh lalat yang berasal dari tumpukan sampah di area pasar.

Sementara itu bagi masyarakat yang menjadi konsumen, kondisi di Pasar Dupa Kencana, terutama di saat hujan, sangat tidak nyaman untuk dikunjungi. Genangan air berlumpur sudah terlihat sejak memasuki areal parkir yang belum diaspal dan disemenisasi. Konsumen yang memasuki ke dalam pasar pun harus sering menutup hidung karena baunya yang menyengat yang muncul dari saluran air kotor yang menggenang. Tumpukan sampah basah dan organik lainnya membuat kondisi pasar semakin berbau dan tidak nyaman untuk dilihat. Sebenarnya para pedagang juga merasakan kondisi yang sama namun oleh karena mereka lebih terbiasa dengan keadaan tersebut, maka reaksi yang muncul tidak sedrastis yang muncul pada masyarakat konsumen maupun penduduk sekitar.

Dengan berbagai fenomena tersebut, rasanya sudah saatnya pemerintah mencanangkan program revitalisasi Pasar Dupa Kencana yang juga menjadi cerminan kondisi pasar-pasar tradisional lainnya di Pekanbaru. Penelitian ini dimaksudkan untuk memberikan gambaran komprehensif kepada pengelola Pasar Dupa dan juga pemerintah mengenai urgensi pelaksanaan revitalisasi Pasar Dupa, dengan mempertimbangkan bagaimana persepsi masyarakat yang menjadi konsumen tetap pasar tradisional tersebut. Hal ini penting 
untuk dilakukan penelitian sehingga pihakpihak berkepentingan memiliki dasar sosial yang cukup kuat untuk segera melaksanakan perbaikan kondisi pasar, sebab pedagang dan masyarakat merupakan dua pihak yang paling intens berinteraksi dengan lingkungan pasar. Dengan demikian maka tujuan dari penelitian ini adalah untuk mengetahui bagaimana persepsi masyarakat dan tingkat keinginannya untuk dilakukannya revitalisasi Pasar Dupa Kencana serta menganalisis besar pengaruh kausalitas dari aspek persepsi terhadap keinginan revitalisasi.

\section{METODE PENELITIAN}

Jenis penelitian dilakukan dengan pendekatan deskriptif kuantitatif untuk menguji aspek korelasional dari faktor-faktor prediktor (independen) terhadap variabel independen. Data-data penelitian bersifat primer dan dikumpulkan dengan mempergunakan kuesioner tertutup. Populasi penelitian adalah masyarakat di sekitar Pasar Dupa Kencana Pekanbaru, baik yang menjadi konsumen pasar maupun penduduk yang bermukim di dekat lokasi pasar. Pembatasan jumlah sampel mengacu kepada saran dari Hair (dalam Ferdinand, 2006), bahwa ukuran sampel minimum yang digunakan dalam penelitian survei dapat dihitung dengan cara: 5 hingga 10 dikali jumlah indikator variabel. Jumlah indikator variabel dalam penelitian ini adalah sebanyak 10 item. Sehingga dengan demikian, ukuran sampelnya menjadi: $7 \times 10=70$ responden. Pemilihan sampel dilakukan secara convenience sampling. Adapun proses pengujian dilakukan secara parametrik dengan mempergunakan alat bantu SPSS 22 for windows.

\section{HASIL}

Kondisi umum di Pasar Dupa Kencana berada pada kondisi buruk. Hal ini ditandai dengan persepsi buruk yang dimiliki masyarakat dalam memandang keberadaan dan kondisi lingkungan di Pasar Dupa Kencana. Namun begitu, terkait dengan revitalisasi, masyarakat hanya menginginkan agar revitalisasi bisa dilakukan dengan cara zoning dan bukan dengan revitalisasi total maupun relokasi. Hal ini sejalan dengan hasil analisis yang menunjukkan bahwa persepsi masyarakat memberikan pengaruh yang negatif namun tidak signifikan terhadap keinginan untuk dilakukannya revitalisasi pada Pasar Dupa Kencana.

\section{PEMBAHASAN}

\section{Persepsi Masyarakat Pada Kondisi Pasar Dupa Kencana}

Hasil analisis deskriptif menunjukkan bahwa secara umum persepsi masyarakat masih tergolong buruk pada kondisi Pasar Dupa Kencana, sebagaimana yang tampak pada tabel berikut:

Tabel 1 : Analisis Persepsi Masyarakat

\begin{tabular}{|c|c|c|c|}
\hline No & $\begin{array}{l}\text { Indikator } \\
\text { Persepsi }\end{array}$ & Skor & $\begin{array}{l}\text { Kriteria } \\
\text { Persepsi }\end{array}$ \\
\hline 1 & Pencahayaan & 236 & Bagus \\
\hline 2 & $\begin{array}{l}\text { Sirkulasi } \\
\text { udara/suhu }\end{array}$ & 154 & Buruk \\
\hline 3 & $\begin{array}{l}\text { Pengelolaan } \\
\text { sampah }\end{array}$ & 120 & Buruk \\
\hline 4 & Saluran air kotor & 135 & Buruk \\
\hline 5 & Fasilitas toilet & 191 & Cukup buruk \\
\hline 6 & $\begin{array}{l}\text { Pengelolaan } \\
\text { parkir }\end{array}$ & 139 & Buruk \\
\hline 7 & Pengelolaan bau & 120 & Buruk \\
\hline & $\begin{array}{c}\text { Rata-rata } \\
\text { persepsi }\end{array}$ & 156 & Buruk \\
\hline
\end{tabular}

Sumber: Data olahan

Hasil yang sama juga disimpulkan dari hasil riset Hasbiah (2010) yang menyatakan bahwa pasar tradisional di kota Makasar belum dapat terbebas dari citra negatif sebagai tempat yang kumuh, semrawut, becek, kotor, kriminalitas tinggi, tidak nyaman, fasilitas minim (tempat parkir terbatas, toilet tidak terawat, tempat sampah berbau tidak sedap dan menyengat, instalasi listrik yang rentan terbakar, dan lorong-lorong yang sempit). Pasar tradisional juga masih dipenuhi oleh banyak pedagang informal (biasanya PKL) yang tidak tertib, sulit diatur. Pedagang kurang disiplin dalam memelihara kebersihan, ketertiban dan keindahan pasar, yang ternyata juga dibiarkan oleh pengelola yang juga kurang memiliki kesadaran/ pengetahuan lingkungan yang memadai. 
Pada dasarnya Pasar Dupa Kencana beroperasi dari pagi hingga sore hari, sehingga sumber cahaya utama diperoleh dari cahaya matahari. Bangunan di pasar sendiri sebagian besar berbahan kayu dan beton dengan atap seng. Struktur atap dibuat agak terbuka sehingga memungkinkan cahaya matahari merembes masuk untuk menerangi area di bawah atap. Pada beberapa kios pun sudah dilengkapi dengan aliran listrik dari PLN. Kondisi ini membuat konsumen tidak mengalami kesulitan dalam hal penglihatannya di pasar. Ini menyebabkan persepsi masyarakat pada aspek pencahayaan berada pada kategori bagus.

Layaknya kondisi-kondisi pasar tradisional lainnya, Pasar Dupa Kencana juga sangat mengandalkan struktur bangunan untuk proses sirkulasi udara yang terjadi di dalamnya. Ada ventilasi-ventilasi kecil di sepanjang dinding bangunan pasar, dan juga atap terbuka yang hanya ditutup dengan terpal plastik, sehingga proses pertukaran udara dapat terjadi. Namun permasalahannya adalah, kondisi berangin tidak selalu dapat dirasakan, karena ketika penulis melakukan proses pengumpulan data, kondisi cuaca di kota Pekanbaru sangat panas dan nyaris tidak berangin. Akibatnya suhu menjadi sangat gerah, terik dan menyengat hingga masuk ke lorong-lorong pasar. Jadi wajar jika kemudian masyarakat menempatkan aspek sirkulasi udara/suhu pada kategori buruk.

Sampah sangat tidak terkelola dengan baik dan higienis di pasar ini. Tempat penampungan sampah menumpuk berharihari, tidak dipisahkan antara sampah organik dan non organik sehingga menyebabkan bau tak sedap, lalat, tikus dan hama lainnya yang berkeliaran di tumpukan sampah. Bahkan di dalam pasar itu sendiri banyak ditemukan tumpukan sampah basah dan plastik berserakan di balik los, atau di pinggirpinggir lapak pedagang. Kondisi pengelolaan sampah di Pasar Dupa Kencana seringkali membuat pemerintah kota gusar dan sudah beberapa kali melayangkan surat peringatan kepada pengelola pasar tradisional swasta ini. Meskipun ada sedikit perbaikan, namun secara umum masalah sampah selalu menjadi problem berulang yang selalu terjadi. Apalagi dengan kondisi politis di kota Pekanbaru saat ini yang menyebabkan terhambatnya kucuran dana kebersihan kota, semakin membuat tumpukan sampah di Pasar Dupa Kencana semakin parah, karena terbatasnya armada dan tenaga pengangkut sampah.

Terdapat saluran-saluran air yang sengaja dibuat di lantai pasar. Namun banyak sekali sampah yang menyumbat saluran air tersebut, sehingga genangan air berwarna kehitaman dan berbau tak sedap itu pun cukup mengganggu orang di sekitarnya. Limbah cair bekas ikan, daging, kotoran ayam dan lain sebagainya dialirkan begitu saja dalam saluran air yang terbuka, dan bahkan ada saluran-saluran yang sengaja dibuat semi permanen yang mengalir ke parit besar/sungai di bagian belakang pasar. Dengan kondisi yang demikian maka wajar jika kemudian masyarakat memberi skor buruk terhadap pengelolaan air limbah pasar ini.

Pasar Dupa Kencana hanya memiliki 1 unit toilet umum, yang terdiri dari bagian terbuka untuk buang air kecil dan satu kamar mandi tertutup dengan kloset jongkok. Satu unit tanki air kapasitas 250 liter berada di atas dak kamar mandi. Sumber air toilet merupakan air tanah yang disedot dengan menggunakan satu unit pompa air. Melihat kondisinya, menurut penulis memang cukup bersih meskipun banyak bagian di tembok yang telah berlumut dan menguning. Pasokan air cukup bagus meskipun keruh dan sedikit berbau. Seorang petugas kebersihan yang dibayar oleh koperasi pedagang pasar selalu membersihkan toilet di pagi dan sore hari.

Permasalahan parkir di Pasar Dupa Kencana adalah penataan kendaraan milik konsumen, pedagang dan pemasok tidak diatur dengan tertib, sehingga saling tumpang tindih. Ketika truk-truk barang dari pemasok menurunkan barang, seringkali menghalangi kendaraan lain untuk masuk atau keluar dari area parkir. Belum lagi perilaku sebagian pedagang dan masyarakat pengguna sepeda motor yang 
begitu saja memarkirkan kendaraannya di sembarang tempat, bahkan hingga di loronglorong pasar, sehingga membuat pasar semakin sesak ketika pagi hari dimana merupakan waktu puncak keramaian pasar. Banyak konsumen yang enggan masuk dan memarkirkan kendaraannya di dalam area pasar dan memilih untuk memparkirkan kendaraannya di pinggir jalan raya, sehingga membuat lalu lintas menjadi terhambat karena kendaraan yang melintas harus melambatkan lajunya karena banyak kendaraan yang parkir di sisi kiri dan kanan badan jalan.

Fenomena di pasar-pasar tradisional di seluruh Indonesia nyaris sama, yaitu kumuh, becek dan berbau tidak sedap. Aroma barang dagangan basah, bau pesing, saluran air yang tersumbat dan tumpukan sampah membuat penciuman di pasar-pasar tradisional menjadi kurang nyaman. Hal ini terasa juga di Pasar Dupa Kencana, dimana area tumpukan sampah berada tidak jauh dari area pedagang, saluran air kehitaman dan berbau serta tumpukan kotoran ayam, jeroan ikan dan daging cukup menyengat penciuman bagi orang yang tak terbiasa. Terlihat beberapa konsumen juga selalu menutup hidungnya setiap kali melintas pada bagian-bagian pasar tertentu. Hal inilah yang kemudian menyebabkan persepsi responden masyarakat menjadi buruk.

\section{Intensitas Keinginan Masyarakat Merevitalisasi Pasar Dupa Kencana}

Keinginan masyarakat agar dilakukannya revitalisasi terhadap Pasar Dupa Kencana dalam penelitian ini diukur melalui keinginan dilakukannya revitalisasi per zoning/bagian, revitalisasi total, dan relokasi pasar.

Tabel 2: Analisis Intensitas Keinginan Revitalisasi Pada Masyarakat

\begin{tabular}{|c|l|c|c|}
\hline No & \multicolumn{1}{|c|}{$\begin{array}{c}\text { Indikator } \\
\text { Revitalisasi }\end{array}$} & Skor & $\begin{array}{c}\text { Kriteria } \\
\text { Persepsi }\end{array}$ \\
\hline 1 & $\begin{array}{l}\text { Revitalisasi } \\
\text { perzoning }\end{array}$ & 255 & Menginginkan \\
\hline 2 & Revitalisasi total & 149 & Menolak \\
\hline 3 & Relokasi & 153 & Menolak \\
\hline \multicolumn{2}{|c|}{$\begin{array}{c}\text { Rata-rata } \\
\text { persepsi }\end{array}$} & $\mathbf{1 8 5 . 6 7}$ & Netral \\
\hline
\end{tabular}

Sumber: Data olahan
Masyarakat bersikap netral dalam hal revitalisasi Pasar Dupa Kencana. Hanya pada opsi revitalisasi perzoning (bertahap dan sebagian) saja yang ditanggapi secara positif, sementara untuk revitalisasi total dan relokasi masyarakat dengan tegas menyatakan menolak. Mengingat kondisi fisik dan non fisik di Pasar Dupa Kencana, maka memang diperlukan dilakukan revitalisasi terhadap indikator-indikator sebagaimana yang telah dijelaskan sebelumnya. Terkait dengan masih buruknya persepsi responden maka muncul keinginan masyarakat agar dilakukan revitalisasi dengan metode zoning. Dengan metode ini maka pedagang masih bisa berjualan di tempat-tempat yang belum terkena program renovasi. Bagi masyarakat, renovasi dengan sistem zoning juga memberikan kesempatan agar bisa tetap berbelanja di pasar tersebut.

Revitalisasi total berarti "memaksa" seluruh pedagang menghentikan aktivitas berjualan di Pasar Dupa Kencana untuk sementara waktu hingga bangunan pasar selesai direnovasi secara keseluruhan. Cara seperti ini banyak ditolak karena secara mendasar dipandang mematikan sumber nafkah pedagang sekaligus juga membuat masyarakat kesulitan untuk berbelanja. Meskipun sebenarnya opsi seperti ini bisa diantisipasi dengan penyediaan lahan berjualan sementara, namun tetap saja sering ditolak karena biasanya lahan yang disediakan berada jauh dari lokasi asal, sulit transportasi, lebih tidak nyaman dari pasar sebelumnya, dan berbagai argumentasi lain yang dikemukakan yang pada intinya para pedagang takut kehilangan konsumen apabila dipindahkan ke lokasi penampungan sementara. Belum lagi kekhawatiran jika bangunan baru akan memiliki konsekuensi biaya sewa yang mahal yang harus dibayar oleh pedagang. Masyarakat pada konteks penelitian ini menolak dilakukannya revitalisasi total.

Opsi relokasi adalah langkah yang lebih ekstrim yang bisa dilakukan untuk mengatasi permasalahan lingkungan di Pasar Dupa Kencana. Pada kenyataannya 
opsi ini ditolak baik oleh masyarakat maupun pedagang. Jika melihat bagaimana tanggapan penolakan masyarakat dan pedagang pada opsi revitalisasi total, maka tanggapan penolakan lebih kuat terhadap opsi relokasi sudah dapat diduga akan terjadi dalam penelitian ini. Relokasi berarti memindahkan pasar secara total dan permanen ke tempat yang baru. Artinya masyarakat dan pedagang akan menghentikan kebiasaan berjualan dan berbelanja yang telah puluhan tahun di Pasar Dupa Kencana. Secara psikologis ini tentu memberatkan.

Bagi masyarakat pemukim di sekitar lokasi Pasar Dupa Kencana yang selama ini menjadi konsumen, relokasi pasar hanya akan membawa kesulitan karena kepraktisan jarak rumah-pasar yang selama ini dirasakan kemungkinan besar akan hilang, apalagi jika lokasi yang baru memiliki jarak yang jauh dari rumah konsumen. Artinya ada kemungkinan penambahan biaya ekonomi dan inefisiensi waktu yang harus diterima oleh masyarakat sekitar yang selama ini menjadi konsumen di Pasar Dupa Kencana. Alasan inilah yang membuat masyarakat menolak jika revitalisasi pasar dilakukan dengan opsi merelokasi pasar ke tempat yang baru.

\section{Pengaruh Persepsi Masyarakat Terhadap Keinginan Revitalisasi}

Untuk menentukan apakah besaran pengaruh yang terjadi memiliki dampak signifikan atau tidak dapat dilihat pada tabel berikut ini. Jika nilai $t_{\text {statistik }}$ lebih besar $t_{\text {tabel }}$ maka sifat hubungan/pengaruh yang terjadi adalah signifikan. Sedangkan jika nilai $t_{\text {statistik }}$ lebih kecil dari nilai $t_{\text {tabel }}$ maka sifat hubungan/pengaruh yang terjadi adalah tidak signifikan.

\section{Tabel 3 :Hasil Pengujian Signifikansi}

\begin{tabular}{|l|c|c|c|c|}
\hline & $\begin{array}{c}\text { Nilai } \\
\text { Koefisien } \\
\text { Regresi }\end{array}$ & $\begin{array}{c}\text { Nilai } \\
\mathrm{t}_{\text {statistik }}\end{array}$ & $\begin{array}{c}\text { Nilai } \\
\mathrm{t}_{\text {tabel }}\end{array}$ & $\begin{array}{c}\text { Kriteria } \\
\text { Hubungan } \\
\text { Yang } \\
\text { Terjadi }\end{array}$ \\
\hline $\begin{array}{l}\text { Persepsi } \\
\rightarrow \text { Revitalisasi }\end{array}$ & -0.013 & -.014 & - & $\begin{array}{c}\text { Tidak } \\
\text { Signifikan }\end{array}$ \\
\hline
\end{tabular}

Sumber: Data olahan
Koefisien regresi persepsi masyarakat menunjukkan simbol negatif (-) sehingga dapat diinterpretasikan bahwa, jika persepsi masyarakat menunjukkan perbaikan atau meningkat sebesar satu satuan, maka keinginan untuk dilakukannya revitalisasi pasar akan menurun sebesar 0,013. Nilai $\mathrm{t}_{\text {tabel }}-0,014>\mathrm{t}_{\text {hitung }}-1,995$ dengan nilai sig. $\mathrm{t}$ $0,917>\alpha 0,05$. Dengan hasil ini maka disimpulkan bahwa, persepsi masyarakat terhadap kondisi lingkungan pasar berpengaruh negatif namun tidak signifikan terhadap keinginan untuk dilakukannya revitalisasi Pasar Dupa Kencana. Semakin buruk persepsi masyakarat dalam menilai kondisi lingkungan Pasar Dupa Kencana, maka semakin kuat keinginannya agar dilakukan revitalisasi pada pasar tersebut. Sebaliknya, keinginan melakukan revitalisasi akan semakin rendah apabila masyarakat sudah mempersepsikan kondisi Pasar Dupa Kencana dalam keadaan yang memuaskan.

Hanya saja pada penelitian ini menunjukkan bahwa besar pengaruh yang terjadi tidak signifikan. Maknanya, meskipun secara umum masyarakat memiliki persepsi yang buruk pada kondisi Pasar Dupa Kencana, namun hal tersebut tidak serta merta membuat masyarakat berkenan apabila pihak berwenang melakukan revitalisasi total pada pasar atau bahkan merelokasi pasar ke tempat lain. Jika pun dilakukan revitalisasi maka masyarakat mengharapkan agar prosesnya dilakukan perzoning atau bagian per bagian, sehingga tidak menyulitkan masyarakat sekitar untuk bisa berbelanja kebutuhan hidupnya di Pasar Dupa Kencana.

\section{SIMPULAN}

Masyarakat pada umumnya masih mempersepsikan kondisi Pasar Dupa Kencana dalam kondisi buruk. Namun demikian, persepsi buruk tersebut tidak secara signifikan mempengaruhi munculnya keinginan kuat pada masyarakat agar dilakukan revitalisasi total maupun relokasi pada pasar. Jika pun akan dilakukan revitalisasi pada Pasar Dupa Kencana 
tersebut, masyarakat menginginkan agar prosesnya dilakukan perzoning, sehingga tidak mengganggu aktivitas mereka bertransaksi di pasar.

\section{DAFTAR RUJUKAN}

Ferdinand, Augusty. 2006. Metode Penelitian Manajemen. Badan Penerbit Universitas Diponegoro, Semarang

Hasbiah, Sitti. 2010. Model Revitalisasi Pasar Tradisional di Kota Makassar. Riset tidak dipublikasikan, Universitas Negeri Makassar

Muslimin, L., F. Indriati, dan T. Widayanti. 2006. Kajian Model Pengembangan Pasar Tradisional. Buletin Ilmiah: Penelitian dan Pengembangan Perdagangan)
Slamet, Rokhmad. 2010. Analisis Daya Tarik dan Strategi Manajemen Pasar Tradisional. Jurnal Ilmiah Ekonomi Akuntansi Manajemen Pelita Ilmu, vol. 8 , No. 2.

Sulistyo. H., dan B. Cahyono. 2010. Model Pengembangan Pasar Tradisional Menuju Pasar Sehat di Kota Semarang. Jurnal Ekobis, Vol. 11, No. 2, Juli 2010

http://www.riauterkini.com, tanggal $5 / 2 / 2011$ dan $8 / 2 / 2011$ 